\title{
Vascular endothelial growth factor-A (VEGF-A) and chemokine ligand-2 (CCL2) in amyotrophic lateral sclerosis (ALS) patients
}

Pawan K Gupta ${ }^{1 \dagger}$, Sudesh Prabhakar ${ }^{1 \dagger}$, Suresh Sharma ${ }^{2}$ and Akshay Anand ${ }^{1 *}$

\author{
Abstract \\ Correction to Gupta P K, Prabhakar S, Sharma S, Anand A. Vascular endothelial growth factor-A (VEGF-A) and \\ chemokine ligand-2 (CCL2) in amyotrophic lateral sclerosis (ALS) patients. Journal of Neuroinflammation 8:47.
}

\section{Correction}

The authors observe that, in Table two of our study [1], crude ORs and adjusted ORs for serum VEGFA were also repeated for CSF VEGFA, however, these values for CSF VEGFA are different from serum VEGFA. Correct OR values of CSF VEGFA are given below.

Smoking: crude OR $(95 \% \mathrm{CI})=1.7(0.3-9.1), \mathrm{p}=0.4$; adj OR $(95 \% \mathrm{CI})=0.6(0.08-4.4), \mathrm{p}=0.6]$.

Alcohol consumption: [crude OR $(95 \% \mathrm{CI})=0.6(0.1$ 2.2), $\mathrm{p}=0.4$; adj OR $(95 \% \mathrm{CI})=0.8(0.1-4.4), \mathrm{p}=0.8]$.

Meat consumption: [crude $\mathrm{OR}(95 \% \mathrm{CI})=2.2(0.6-7.7)$, $\mathrm{p}=0.2$; adj OR $(95 \% \mathrm{CI})=2.1(0.5-7.7), \mathrm{p}=0.2]$.

\section{Author details}

'Department of Neurology, Post Graduate Institute of Medical Education and Research (PGIMER), Chandigarh-160012, India. ${ }^{2}$ Department of Statistics,

Panjab University, Chandigarh-160012, India.

Received: 8 August 2011 Accepted: 11 August 2011

Published: 11 August 2011

\section{Reference}

1. Gupta PK, Prabhakar S, Sharma S, Anand A: Vascular endothelial growth factor-A (VEGF-A) and chemokine ligand-2 (CCL2) in amyotrophic lateral sclerosis (ALS) patients. J Neuroinflammation 8:47.

\section{doi:10.1186/1742-2094-8-97 \\ Cite this article as: Gupta et al:: Vascular endothelial growth factor-A (VEGF-A) and chemokine ligand-2 (CCL2) in amyotrophic lateral sclerosis (ALS) patients. Journal of Neuroinflammation 2011 8:97.}

\footnotetext{
* Correspondence: akshay1anand@rediffmail.com

† Contributed equally

'Department of Neurology, Post Graduate Institute of Medical Education and Research (PGIMER), Chandigarh-160012, India

Full list of author information is available at the end of the article
}

Submit your next manuscript to BioMed Central and take full advantage of:

- Convenient online submission

- Thorough peer review

- No space constraints or color figure charges

- Immediate publication on acceptance

- Inclusion in PubMed, CAS, Scopus and Google Scholar

- Research which is freely available for redistribution

Submit your manuscript at www.biomedcentral.com/submit
() Biomed Central 